\title{
IMPLEMENTATION OF FISCAL DECENTRALIZATION IN INDONESIA: 2001-2009
}

\author{
Nursini \\ Faculty of Economics, Hasanuddin University \\ Kampus Baru Tamalanrea Jalan Perintis Kemerdekaan Km.10 \\ E -mail: nini_mahmud@yahoo.com
}

Diterima 10 Juni 2011 / Disetujui 1 April 2012

\begin{abstract}
In Indonesia, the implementation of fiscal decentralization has entered the $9^{\text {th }}$ year, however, so far many problems and obstacles which is faced during the implementation to stimulate economic growth and reduce poverty. This study aims to analyze: trend of government expenditure in decentralization era and regional autonomy during 2001-2009 and fiscal decentralization degree in Indonesia. This objective is achieved through descriptive analysis using secondary data for 2001-2009. The result shows central government expenditure tends to decreased and transfer expenditure increased significantly every year in absolutely, but annual growth rate fluctuated considerably. This indicates the allocation portion of the transfers was unstable. The largest component of transfers is fund balance and tends to increase every year significantly, fiscal decentralization degree at districts/city and province increased in 2007-2008. It is recommended to regional government to allocate public interest bigger than for government administration such as personnel government spending.
\end{abstract}

Keywords: fiscal decentralization, regional autonomy, government expenditure, transfer

\begin{abstract}
Abstrak: Di Indonesia, pelaksanaan desentralisasi fiskal sudah memasuki tahun ke-9, namun masih banyak persoalan dan hambatan yang dihadapi terutama dalam mendorong pertumbuhan ekonomi dan penurunan kemiskinan. Penelitian ini bertujuan untuk menganalisis: perkembangan pengeluaran pemerintah dalam era desentralisasi dan otonomi daerah untuk periode 2001-2009 dan derajat desentralisasi fiskal di Indonesia. Tujuan ini dicapai melalui analisis deskriptif dengan menggunakan data sekunder periode 2001-2009. Hasil penelitian menunjukkan: perkembangan pengeluaran pemerintah pusat cenderung menurun dan transfer pemerintah meningkat cukup signifikan setiap tahun secara absolute, tetapi tingkat pertumbuhan berfluktuasi. Ini berarti bahwa selama periode desentralisasi, porsi alokasi transfer ke daerah tidak stabil. Komponen terbesar pengeluaran transfer adalah dana perimbangan dan cenderung meningkat setiap tahun secara signifikan, derajat desentralisasi fiskal untuk kabupaten/kota dan provinsi meningkat selama dua tahun terakhir, 2007-2008. Direkomendasikan kepada pemerintah daerah untuk mengalokasikan anggaran lebih besar kepada kepentingan publik daripada administrasi pemerintahan seperti belanja pegawai negeri.
\end{abstract}

Kata kunci: desentralisasi fiskal, otonomi daerah, pengeluaran pemerintah, transfer

\section{INTRODUCTION}

Fiscal decentralization is one of the most interesting issues in the theory of state and local finance, and has helped to globalize the world. Fiscal decentralization is expected to be able to overcome the various problems being faced by countries, including issues of poverty and instability of economic growth. Through fiscal decentralization, the government can recognize the needs of society so that public services become more efficient and touch the real needs of society which in turn can encourage eco- 
nomic growth and reduce poverty.

Many empirical studies have examined the impact of fiscal decentralization on the economy of a country such as economic growth and poverty. The relationship between fiscal decentralization and economic growth has been examined by many empirical studies (Phillips and Woller, 1997; Zhang and Zou, 1998; and Martinez-Vazquez and McNab, 2001; Rodriguez-Pose and Kroijer, 2009). Some empirical studies indicate that the relationship between the two variables is still a debate. Fiscal decentralization has a negative effect on economic growth in China (Zhang and Zou, 1998), Phillips and Woller (1997) in developing countries and a positive influence on economic growth in developed countries (Martinez-Vazquez and McNab, 2001; Rodriguez-Pose and Kroijer, 2009). Several other studies examined the relationship between fiscal decentralization and poverty (Martinez-Vazquez and McNab, 2001, Susan, 2005). Martinez-Vazquez and McNab, (2001) concluded that the policy of spending more precise than the revenue policy. World Bank (2007) recommends that the problems of poverty can be overcome by making the pro poor budgeting.

There are three indicators of fiscal decentralization that are commonly used by many empirical studies: (1) Decentralization of expenditure is defined as the ratio of total expenditure in each district/city in the region budget (APBD) of total government expenditures (State Budget) (Phillips and Woller, 1997; Zhang and Zou, 1998; Rodriquez-Pose and Kroijer, 2009). This shows the relative size of government expenditures between regional governments and the central government, (2) Decentralization of development expenditures is defined as the ratio between the total development expenditure of each district/city (APBD) relative to the total national development expenditure (APBN). This variable indicates the relative size of government expenditure in development between local and central government. From this ratio it can be seen whether the regional government is in a good position to carry out public sector investment or not. If there is a positive relationship between these variables with economic growth, the regional government is in a good position, (3) Revenue decentralization is defined as the ratio between the total revenue of each district/city does not include subsidies to total government revenue (Philips and Woller, 1997). This variable expresses the relative amount of revenue regional governments against central governments.

Fiscal decentralization policy and regional autonomy has been implemented in Indonesia since 2001 and aims to support the achievement of national development for the creation of prosperity of the community. During the period of 2001-2010, a lot of expectations should be realized, however it should be recognized that many problems and constraints are still faced during the implementation of fiscal decentralization.

This study aims: (1) to analyze the trend of government expenditure in Indonesia, (2) to analyze the degree of fiscal decentralization in the era of decentralization and regional autonomy for the period of 2001-2009.

\section{RESEARCH METHOD}

This research used descriptive research approach. The type of data is secondary data which collected from various sources inclduded internet, World Bank reports, and other documents. Secondary data were analyzed through descriptive statistical models that described the development of regional (district/city) revenue and expenditure in the decentralization era and the trend of indicators of fiscal decentralization in Indonesia for the last three years (2007-2009). Indicator of fiscal decentralization which analyzed was expenditure side which measured by ratio of district/city government expenditure to total national expenditures.

\section{RESULTS AND ANALYSIS}

\section{Trend of State Government Expenditure}

Fiscal decentralization has several objectives as follows (Anggito, 2008): (1) to reduce fiscal dis- 
parities between central and regional governments (vertical fiscal imbalance) and regions (horizontal fiscal imbalance), (2) to improve the quality of public services in the area and reduce public service gaps among regions, (3) to improve the efficiency of utilization of national resources, 4) to strict governance, transparency, and accountability in the allocation of activities transferred to the regions targeted, timely, efficiency, and fair, and (5) to support sustainability fiscal macroeconomic policy.

It is understood, of course, that it is impossible to achieve fully all these objectives, everywhere and all the times. Some goals may conflict with one another, and, to the extent that objectives are not consistent, hard choices will have to be made. At least, however, the purpose of this policy is to provide a basis for evaluating the relative success of the implementation of a fiscal decentralization program. In addition, it is noted that the ultimate goal of all these goals is to create greater well-being of a better society through increased regional economic growth.

To find out how far one or more objective is reached, the necessary fiscal decentralization indicators are commonly used by many countries. Here are some indicators of fiscal decentralization is applied in Indonesia (Khuzaini, 2006): (1) Decentralization of expenditure, (2) decentralization of revenues, and (3) decentralization of development expenditures. The same opinion by Martinez-Vazquez and Sri Mulyani (2003), the degree of fiscal decentralization measures can be seen from the sub-national share to national revenue and expenditure. Furthermore, they argued that these measures are far from perfect proxies of the degree of decentralization their use is common and, within limits, can be instructive.

The main instrument of fiscal decentralization is the transfer of central government to regional governments consisting of balance fund and the special autonomy fund. Balance fund consists of revenue sharing, the General Allocation Fund (DAU), and the special allocation fund (DAK). In the new budget structure, the expenditure component is composed of two areas: central government expenditure at $\mathrm{Na}-$ tional level (centers) and regional expenditure.
Regional expenditure includes expenditure by the central government in the region (through Ministries/Institution; K/L, vertical funds, deconcentration funds, the duty of assistance funds) and transfers to the region through APBD.

As illustration in 2008, central government expenditure to the regions is 41 percent consisted of centers government expenditure in the region is 12 percent (by $\mathrm{K} / \mathrm{L}$; vertical funds, de-concentration funds, and the duty of assistance) and transfers to the regions is 29 percent, while center government expenditures at the national level by 34 percent. In 2009, the state budget funds to the region increased to 76 percent which consists of government expenditure through the $\mathrm{K} / \mathrm{L}$ by 45 percent and transfer to the regions by 31 percent (Figure 1 and 2).

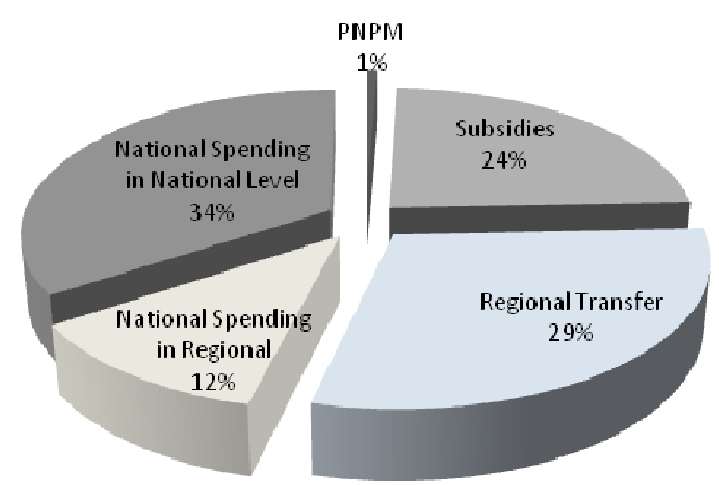

Source: Finance Ministry: Finance Note 2009 (processed data) Figure 1. Composition of Central Government
Expenditure in 2008 (percent)

In addition, there are other programs such as PNPM which has absorbed the State Budget so that the amount of money circulated at the regional level increases. By looking at the development of central government expenditure during the era of regional autonomy and fiscal decentralization seems the central government expenditure decreased and the transfer expenditure increased. In 2008, the largest transfers were allocated to the DAU for 62 percent, the rest is 38 percent which allocated to the DAK, profit-sharing and funds special auton- 
omy (Otsus). But in 2009, transfer to the DAU decreased to 58 percent, the rest is 42 percent is allocated to the other components of the balance funds and funds Otsus.

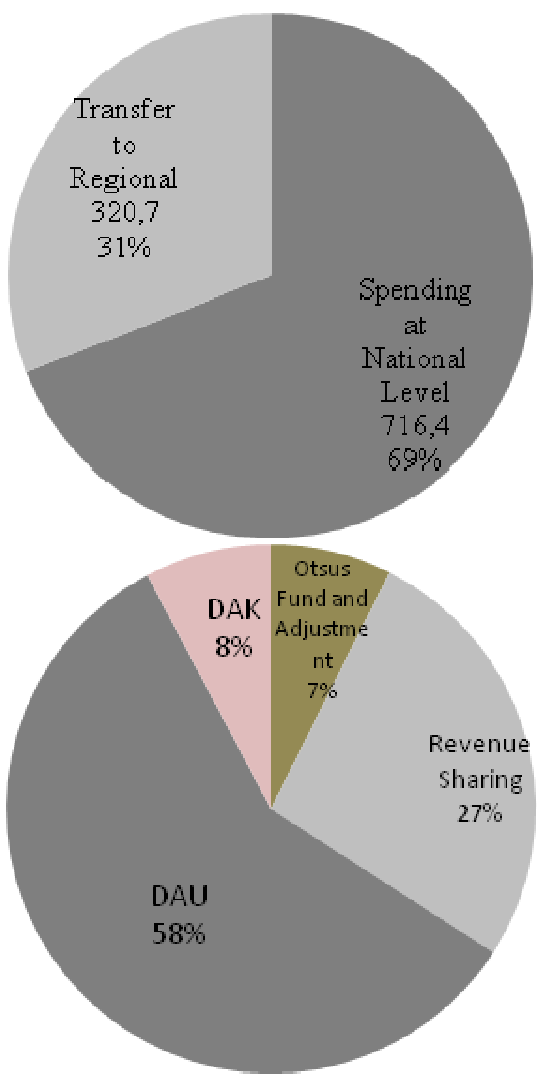

Source: Finance Ministry: Finance Note 2009 (processed data)

Figure 2. Composition of Central Government Expenditure in 2009 (percent)
What is interesting to note further is the development of the State government expenditure over the period 2001-2009. Does the State expenditure significantly affect the national economy in the era of decentralization and local autonomy? In general there is a tendency for the regional expenditure increased every year with an average per year is 18.85 percent, while central government expenditures tend to fluctuate with an average growth reached only 14.22 percent per annum during the period 2001-2009.

In 2001, the allocation of funds transfer to the region of Rp81.1 trillion only covers the balance fund. Since 2002, there was central government policy regarding to Papua is called $\mathrm{Pa}-$ pua Special Autonomy (Otsus Papua), then the allocation of transfer was intended to be sufficiently large in 2002. Transfers increased to $\mathrm{Rp}$ 98.2 trillion in 2002. The trend of transfer to the region can be seen in Figure 3. During the implementation of regional autonomy and fiscal decentralization as stipulated by Law No. 22 of 1999 which replaced the Law No. 32 of 2004 and Law No. 25 of 1999 which had been converted into Law No. 33 of 2004, the trend of financial transfers from central to regional government increased sharply, namely from $\mathrm{Rp}$ 81.1 trillion in 2001 to Rp320.7 trillion in 2009. During this period, the average increase per year was 185.94 trillion. Although in absolute terms the transfers has increased significantly every year, but annual growth rate fluctuated considerably. This means that during the period

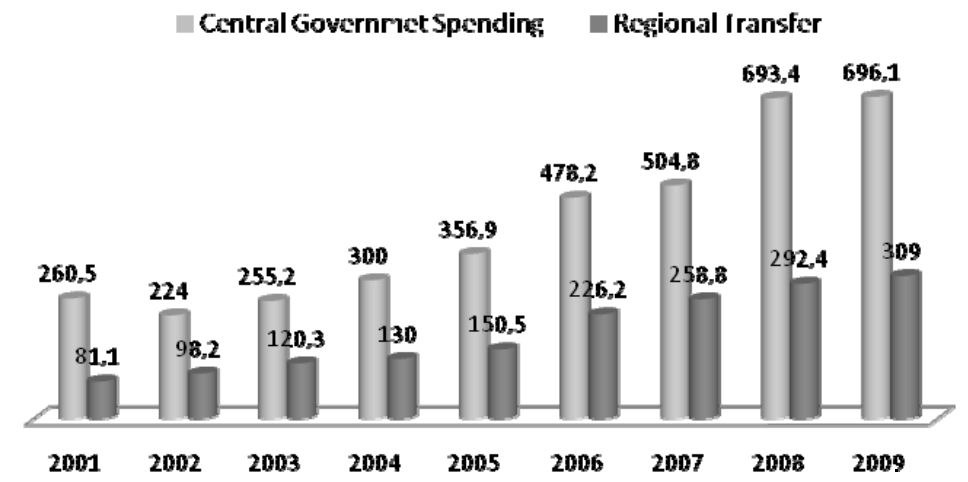

Source: Finance Ministry, Finance Note various editions: processed data

Figure 3. Trend of State Government Expenditure by Composition 2001-2009 (in trillion rupiah) 
of decentralization, the allocation portion of the transfers into the region was unstable. The largest growth rates occurred in the year 2006 is 50 percent, which further decreased to be 9 percent in APBN 2009. This may be caused by the transfer mechanism. Transfer mechanisms by using ad hoc highly depends on the size of the budget each year and causes the transfers is large enough fluctuate each year (Boex and MartinezVazquez, 2001; Marinez-Vazquez and Searle, Bob 2007a, 2007b).

In the 2001-2009 period, the fund balance which is the largest component of transfers to the region, showed a significant increase, from 81 trillion in 2001 to Rp279.6 trillion in 2008, and increased to 297 trillion in APBN 2009. In this period, the fund balance increases by an average of 177 billion per year, or grow by an average of 18 percent per year. This indicates that the implications of fiscal decentralization on the budget allocation to the regions large enough. Of course the budget is expected to encourage the acceleration of the economy in the region which will ultimately improve the welfare of society as a whole in the future.

Among the three components of balance fund, the highest absorptive was occupied by the DAU. Increased allocation of DAU is quite significant from year to year associated with an increased ratio of DAU allocation of net reve- nues. DAU is transferred to the regions using the formula mechanism. During the period 2001 to 2009 , there are three types of calculations DAU: 25 percent of domestic revenues for the period 2001-2003; 25.5 percent of domestic revenues for the period (2004-2005) and 26 percent of domestic revenues over period 2006-2009. During the period 2001-2009, the portion of the DAU allocation experienced significant increases in average of Rp 117 trillion per year, or grow by an average of 16 per cent per year. During this period, the DAU has increased quite sharply in the year 2006, from Rp 88.77 trillion in 2005 to Rp 145.67 trillion in 2006 or grew by 64 percent. During the period 20012009, DAU absorbs 66 percent of the fund balance.

Along with the transfer type as described in the previous section, the application of transfer in Indonesia is dominated by DAU or unconditional grants by Rosen (2008) and general grant by Searle and Martinez-Vazquez (2006). The use of this transfer is fully transferred to regional government without any conditions.

In practice in Indonesia, the use of DAU is more absorbed for routine expenditure especially for payment of government salaries. This means that most of the DAU is clear direction. Meanwhile, a small portion of the DAU is the

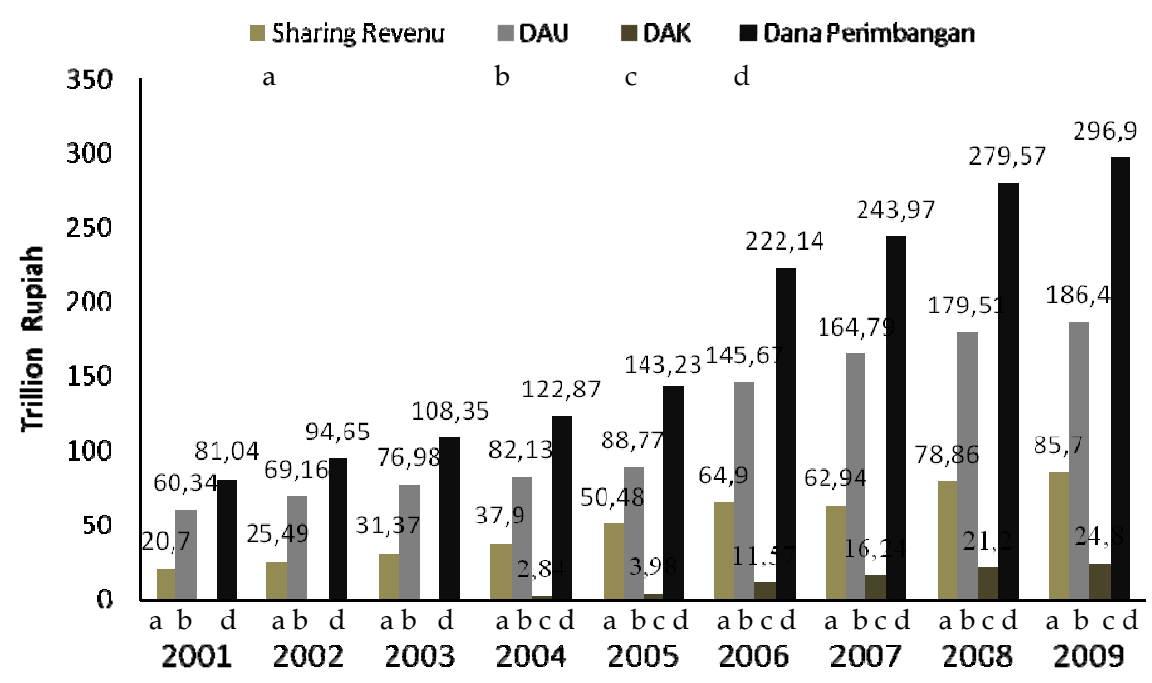

Source: Finance Ministry, Finance Note various editions: processed data

Figure 4. Trend of Balance Fund (Revenue Sharing, DAU, and DAK 2001-2009 (in trillion rupiah) 
authority of regional governments to finance development programs and activities. The small portion of the DAU allocation for development activities demonstrates the limitation of regional governments to provide more public goods. This fact has become a classic problem by regional government since the implementation of regional autonomy, on one side. However, on the other side, on the condition, the regional government must be intelligent and capable to formulate programs and activities planning in accordance with the main priority in order to the provision of public goods needs remain met.

More dominant unconditional transfers not only found in Indonesia, but also in the Philippines. The central government transfers to the sub-national government are of two types: formula-based block grants (the internal revenue allotments or IRA) and ad hoc categorical grants (Ichimura and Bahl 2008). In intergovernmental fiscal transfers, the transfer type is dominated by a block grant which grew by an average 16.5 percent per year during the period 1992-2001. Inversely to the case of United State, the largest transfer type occupied by the transfer conditional or specific purpose (Fisher, 2007).

DAU allocation to the regions is done by using a formula based on the calculation of basic data DAU. Historically since 2001 to 2005, the DAU formula is divided into two main components: the minimum allocation (AM) and the DAU allocation based on the fiscal gap (KF) (Finance Note, 2009). PM is calculated based on a lump-sum component and the proportion of official expenditure. Since the enactment of Law No. 33 of 2004, the effective force since 2006, components of PM and KF are perfected into the Basic Allocation (AD) and the gap Fiscal (CF). DAU allocation is based on the CF component of inter-regional equalization of financial capability, taking into account the difference in the fiscal needs and fiscal capacity of each region. Based on the FG indicator, there are regions that receive less DAU allocation to or greater than other regions because of differences in the fiscal gap. A region that has a large fiscal gap (that is fiscal needs is greater than fiscal capacity the region) receives the DAU with a relatively large number compared with a small fiscal gap.

Based on the DAU allocation formula for the all province, district/city in Indonesia shows that horizontal inequalities are still visible. In 2009, there are five provinces as the largest recipient of DAU allocation that is Province of West Kalimantan, Papua, West Java, East Java and Central Java. While, there are four provinces as the lowest recipient of DAU are

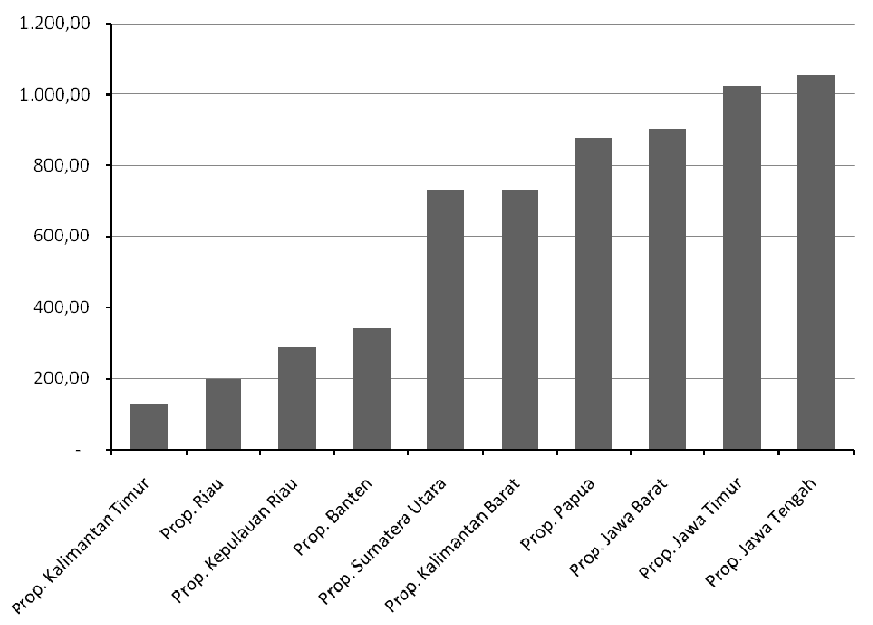

Source: Finance Ministry, Finance Note various editions: processed data

Figure 5. DAU Allocations by Provinces in 2008 (in billion rupiah) (The lowest and the largest proportion) 
East Kalimantan, Riau, Riau Archipelago and Jakarta. Those province are the largest oil producer in Indonesia and therefore they would receive revenue sharing considered large enough. In 2009, the four provinces that still seem to occupy the same position in 2008. What is interesting for this year is that there are several Districts/Cities that do not receive DAU such as District Bengkalis, Rokan Hilir, Siak, Jawa Barat, Kutai District, and South Buru district. It may be because of two considerations: (i) oil-producing districts and (ii) own revenue as DKI Jakarta receives PAD by 11.1 trillion in 2009.

The situation is different when looking at the DAU allocation for the entire District and City. In 2008, four of 542 District/Cities in Indonesia received DAU allocation in the range from 33 to 37 billion, the smallest is Penajam Paser, while five districts/city receives DAU in the range from 959 to 1.063 billion (Figure 6). Among of them, Bogor City received the largest amount of DAU, 1.1 trillion. This fact has not shown the creation of inter-regional fiscal balance. If the government does not make efforts in a more significant for the future, the impact of fiscal decentralization on regional development is increasingly unconvincing.

The second largest component of balance fund is revenue sharing (DBH) with an average of 51 trillion per year for the period 2001-2009
(Figure 4). The DBH absorbed of 27 percent of the fund balance. Based on Law No. 33 of 2004, DBH is calculated based on a certain percentage of domestic shared revenue, either from tax revenues or revenues of natural resources. State revenues derived from tax revenues that shared to the region include personal income tax $(\mathrm{PPh}$ 21 and PPh 25-29 of personal tax payers in the country, Land and Building Tax (PBB), and Land and Building Transfer Fee (BPHTB). Meanwhile, state revenues from natural resources to be shared the region include natural resources (SDA) of petroleum, natural gas, general mining, forestry, and fisheries. Since 2006, natural resource DBH also includes DBH forestry reforestation fund (DBH DR).

Transfer of revenue sharing depends on the size of the state revenue realization shared (DBH taxes and SDA). In line with the increasing of the state revenue realization shared, $\mathrm{DBH}$ to the region has increased each year from $\mathrm{Rp}$ 20.7 trillion in 2001 to $R p 85.7$ trillion in 2009 . Or during the period of realization (2001-2008) increased by an average of 47 trillion per year or an average growth of 21 percent per year. Although DBH is only 27 percent of funds balance, but the average growth per year is greater than the DAU, 16 percent. This indicates that the government attention to the funding mechanisms of DBH is quite significant.

In 2008, the district or city that received the

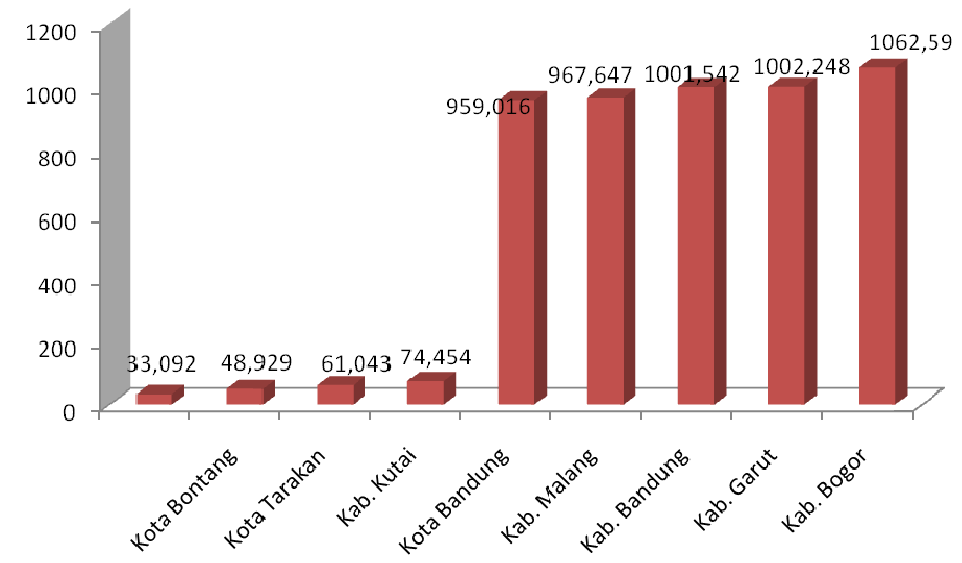

Source: Finance Ministry, Finance Note various editions: processed data

Figure 6. DAU Allocation by District/City Selected (the largest and smallest) in 2008 (in billion rupiah) 


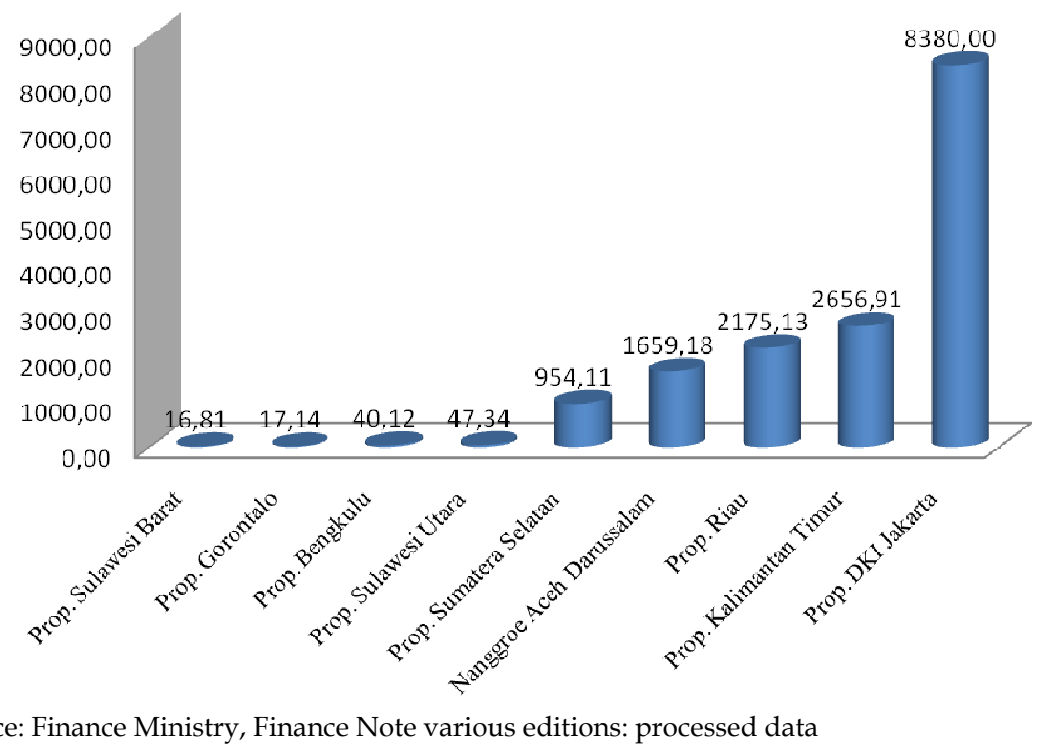
Figure 7. DBH allocations by Provinces (the largest and the lowers) selected in 2008
(in billion rupiah)

highest Natural resources DBH is in East Kalimantan Province that is 38.93 percent of all natural resource $\mathrm{DBH}$, while the district or city that received the lowest Natural resources DBH is in the Province of Yogyakarta that is 0.01 percent of the overall revenues natural resources DBH. Revenue sharing (natural resources and taxes funds) proportion from the total revenue in the entire province in Indonesia is 25.26 percent in 2008 and 24.74 percent in 2009. While at the district or city, the proportion revenue sharing from the total revenue the entire district and City would be 11.13 percent in 2008 and 17 percent in 2009. It seems that the revenue sharing in the district or City is smaller than in the provincial level.

Provinces that received the greatest revenue sharing are generally oil-producing provinces. In 2008, the province who received the largest DBH is DKI Jakarta. DKI Jakarta is not oil-producing, but it has the biggest PAD. The second largest is the East Kalimantan. While, the province that received the lowest revenue sharing is West Sulawesi Province. This province is a new province and is a division of South Sulawesi Province. The district or city that received the smallest revenue sharing is the Alor District and is only 6 billion, while the
Kutai District received the largest revenue sharing with 4,308 billion.

DAK is special transfer to the region which absorbed an average 17 percent of the fund balance in the period of 2001-2009. DAK allocation did not fully meet all the objectives of DAK (Sidik and Kadjatmiko, 2003). There are numerous goals in the design of the DAK such as: (1) the DAK is mainly intended to help fund important needs that could not be estimated in a DAU formula and to assist with funding of expenditures that related to national priorities, (2) The DAK is also used to finance physical capital investment, and (3) the DAK promotes the attainment of a minimum standards, and compensates for benefit/cost spillovers related to priority capital investments. In the beginning of fiscal decentralization policy, the DAK allocation are based only on revenue derived from the country's Reforestation Program.

Within two years of decentralization (20012002), DAK funds allocated for reforestation, which is part of 40 percent of total revenue reforestation funds (Ministry of Finance, Finance Note, 2009). In 2004, DAK Non reforestation allocated for clean water infrastructure and maritime affairs and the fisheries sector. There has been encouraging DAK coverage 
since 2005 in agriculture sectors, environment, family planning and forestry. To demonstrate local commitment in the implementation of DAK, the required matching funds in the budget, at least 10 percent of the amount received in DAK allocation. In line with the addition of fields that are funded through the DAK, DAK realization increases from year to year. Similarly regions that receive DAK also increased due to expansion of the provincial and district or city. East Java is the highest region that received DAK allocation in 2008.

From Figure 3 to 7 shows the transfer of funds from central government to regional governments (provincial and district/city). It can be concluded that the allocation of funds transfers (the fund balance) to the regional government has absorbed most of the state budget. DAU is the largest component of the balance funds. Fund balance is one source of regional government revenue. The presence of the balance of funds as one source of regional revenue affects the structure of regional government budgets. Thus, the structure of regional government budget consists of regional revenues, expenditure and financing. The regional revenue side consist of local own revenue (PAD), fund balance and other local revenues.

One of the purposes of the policy of regional autonomy and fiscal decentralization is the reduction of financial dependence by the regional governments to central government. This means that regional governments are required to increase the potential revenue source that comes from their own region. In this case the question arises how far regional governments have reduced their dependency levels during the implementation of regional autonomy and fiscal decentralization?

\section{The Degree of Fiscal Decentralization in Indonesia}

Act No. 34 of 2000 mentioned that there are 11 (eleven) local taxes granted to regional governments (provincial and district/city) in determining the tax base, tax rates and as well as administrative and types of local taxes and user charge that may be levied by regional governments. However, the Act allows regional governments to add local tax sources and user charges in accordance with predetermined criteria (Simanjuntak and Mahi, 2003). The eleven of the local taxes can be seen in Table 1 .

With the presence of such Act, has the regional government PAD increased significantly? Realization of the sources of regional revenue for all provinces and districts/cities can be seen in Figure 8. For three years (20072009), fund balance position as the largest source of regional revenue with an average of Rp191.45 trillion per year, the second largest revenue is PAD with an average increase of

Table 1. Local Taxes Types Based on Law No.34/2004 in Indonesia

\begin{tabular}{llccccc}
\hline Revenue & \multicolumn{3}{c}{ Responsibility } & \multicolumn{2}{c}{ Disposition revenue } \\
\cline { 2 - 7 } & Base & Rate & Adm & Center & Province & Local \\
\cline { 2 - 7 } Vehicle tax & C,P & P & P & 0 & 30 & 70 \\
Vehicle transfer tax & C,P & P & P & 0 & 30 & 70 \\
Fuel tax & C,P & P & P & 0 & 90 & 10 \\
Exploration tax of surface and & C,P & P & P & 0 & 100 & 0 \\
underground water & & & & & & \\
District/City & & & & & & 100 \\
Hotels tax & C,L & L & L & 0 & 0 & 100 \\
Restaurants taxes & C,L & L & L & 0 & 0 & 100 \\
Entertainment taxes & C,L & L & L & 0 & 0 & 100 \\
Advertisement taxes & C,L & L & L & 0 & 0 & 100 \\
Streetlighting taxes & C,L & L & L & 0 & 0 & 100 \\
Exploration tax of mines (type c) & C,L & L & L & 0 & 0 & 100 \\
Parking tax & C,L & L & L & 0 & 0 & 0 \\
\hline
\end{tabular}

Source: Simanjuntak and Mahi,2003 

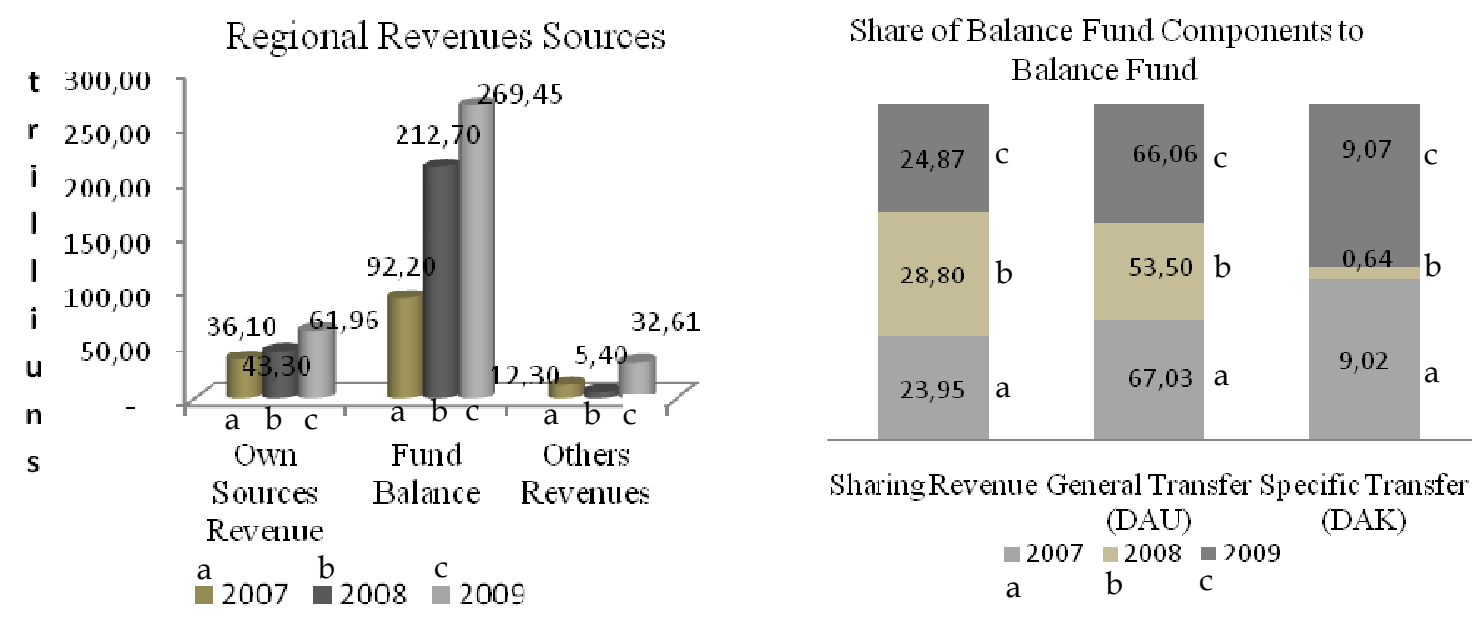

Source: Finance Ministry, various editions (processed data)

Figure 8. Regional Revenue Sources by Composition the whole Provinces and District/ City in Indonesia, 2007-2009

47.12 trillion per year and others PAD by an average Rp16.77 trillion (Figure 8).

This figure shows that during the last three years, there is a trend increase in own source revenue each year, from Rp36.10 trillion in 2007 to Rp61.96 trillion in 2009. However, the average increase only reached 31.52 percent, is smaller than the average increase in fund balance reached 78.68 percent during the 2007-2009 periods. By considering this fact one can say that the contribution of regional government revenue comes from local own revenue to fund all programs and activities is still relatively very low. In other words, the level of regional government dependence on central government is considered big enough. This can be shown from the share fund balance to total regional revenues that reached an average of 73.63 percent over the last three years, while the PAD is only contributing of 19.74 percent. If this condition is still going on in the coming years, then the goal of regional autonomy and fiscal decentralization will not yet achieved optimally.

Figure 9 shows the PAD map by provinces in 2009. Total PAD for all provinces in Indonesia is only recorded at $\operatorname{Rp} 42.5$ trillion. Only four

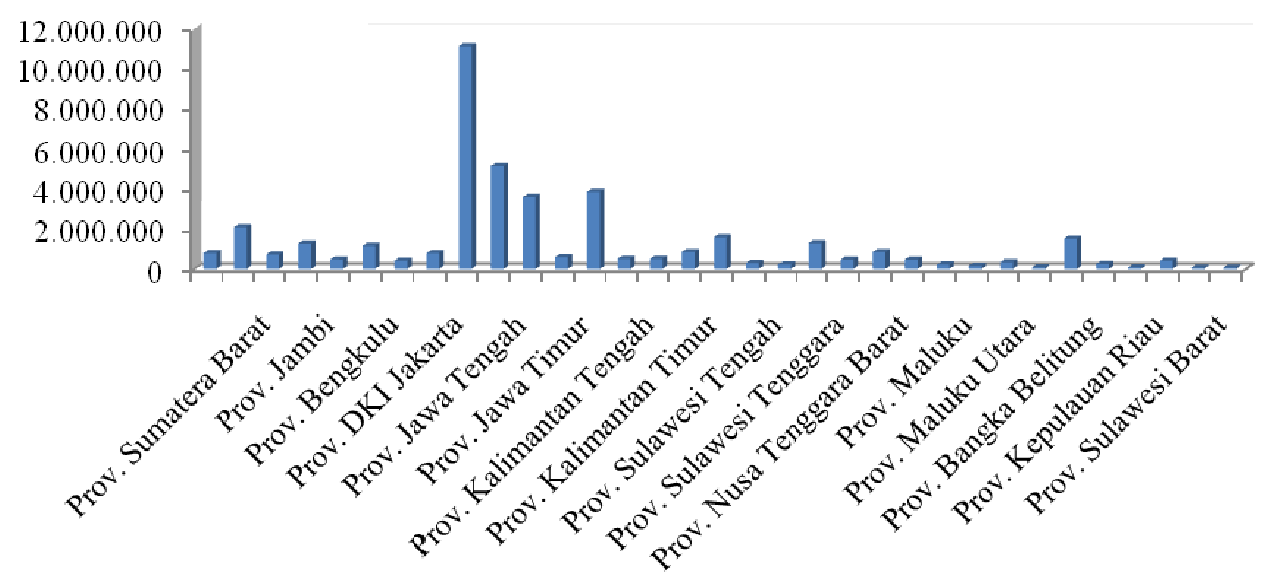

Source: Finance Ministry, Finance Note, 2009

Figure 9. PAD Map by Provinces in 2009 (in Millions rupiah) 


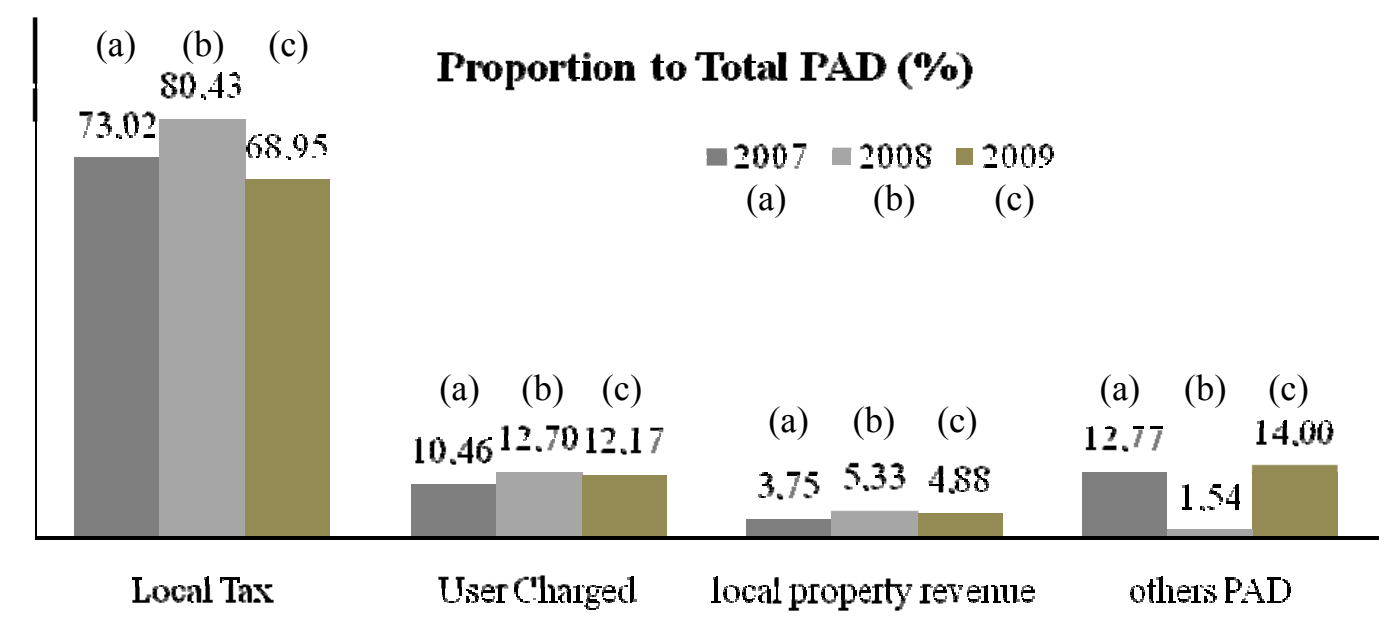

Figure 10. Proportions PAD Sources to Total PAD Provinces and District/City, 2007-2009 (in percent)

provinces of 33 provinces that have PAD over Rp4 trillion, In 2009, the largest own revenue contributor is DKI Jakarta, Rp11.1 trillion (26.16 percent of total revenue) and the lowest is West Sulawesi, Rp64 million or 0.58 percent of total revenue.

If connected with the presence of Act No.34 of 2000 one can say that the tax assignment has not given importance to the increase of own revenue at the regional level (provincial and district/city). There are three main reasons as the cause: (1) most of the potential taxes sources are still taken over by the central government, for example, income tax and oil tax, (2) Regional government does not work optimally to explore potential sources of other taxes, although there was some cases that occurred at the local level with regional government was aggressively collecting taxes from people who seem to harm local communities and investors. Of course, this case was not justified under the Act, and (3) Criteria of local taxes according to the Law is very strict so many PERDA which was rejected by the central government. This indicates that local governments still need to do a variety of policies to encourage increased local revenue without burdening the public. Optimization of increasing revenue through the inten- sification is still badly needed.

Although PAD is a small contribution to the total regional revenue, but it needs to be seen and analyzed types of own revenue sources which provide the largest contribution to the PAD and has prospects in the future. Among the four sources of increased PAD (local taxes, user charge, public enterprises and other PAD), local taxes is the largest contributor to PAD the whole province and district/city in Indonesia, while the user charge is the second largest. Taxes and user charge have a different role between different provincial and district/ city. In general, local tax revenue is the largest own revenue source at the provincial level and at the district or city is the user charge.

During the period 2007-2009, the proportion of local tax revenue to total own revenue fluctuated, but the average is 74.13 percent. This amount was encouraging when compared with other types of own revenue sources. User charge only contributed an average of 11.78 percent, local enterprise is only 4.66 percent and 9.44 percent for other own revenue. Therefore, types of own revenue sources that have better prospects and still need to be increased is local taxes without forgetting the efforts of improving other own revenue sources. 
After reviewing and analyzing the amount of regional government revenues, both from the fund transfer and other local revenue sources, it can be concluded that the total regional revenue is recorded substantial and increased from Rp140.6 trillion in 2007 to Rp364.01 trillion in 2009 or increased by an average of Rp255.34 trillion per year, or grow by 62.56 percent during the period 2007-2009. This trend would provide great meaning to regional governments in funding the provision of public goods. By looking at the magnitude of this amount one can say that the funding is no longer a major obstacle for regional governments. What should be expected to occur is the existence of a positive correlation between the magnitude of the regional revenues and increase of people welfare.

The success of a region depends on the policies of each regional government. The policy can be done through the allocation of regional revenues in programs and activities oriented to the needs of society (public interest), so it can create jobs and reduce the number of poor people. Allocation of regional revenues will be reflected in the allocation of expenditure. There are two components expenditure in the structure of regional budget (APBD) are indirect expenditure and direct expenditure. Indirect expenditure is expenditure that is not directly related to the financing programs and activities. There are eight types of indirect ex- penditures: personnel expenditure, interest rates, subsidy, grants, social assistance, expenditure of the provincial/district/city/village government; financial assistance to the provincial/district/city and village governments; and expenditure unexpected. While direct expenditure is expenditure directly related to the programs and activities. There are three types of direct expenditures: personnel expenditure, expenditure on goods and services, and capital expenditure.

The trend of regional government expenditure in the whole provinces and District/City is still dominated by indirect expenditure with an average per year is about Rp222,319.8 billion. Although it seems a decline in the year 2009 (APBN), but it is expected to increase in its realization. As events in the year 2008, its growth rate reached 153 percent from the previous year. In 2008, the proportion of indirect expenditure of total regional government expenditure is 62 percent. The rest is allocated for direct expenditure by 38 percent. Trend of direct expenditures was relatively stable. The average is $188,194.5$ billion rupiah per year, or an average of 46 percent of total regional government expenditure during the period 20072009.

By looking at the development of direct and indirect expenditures, regional governments still seem to focus on expenditure for government administration rather than of de-

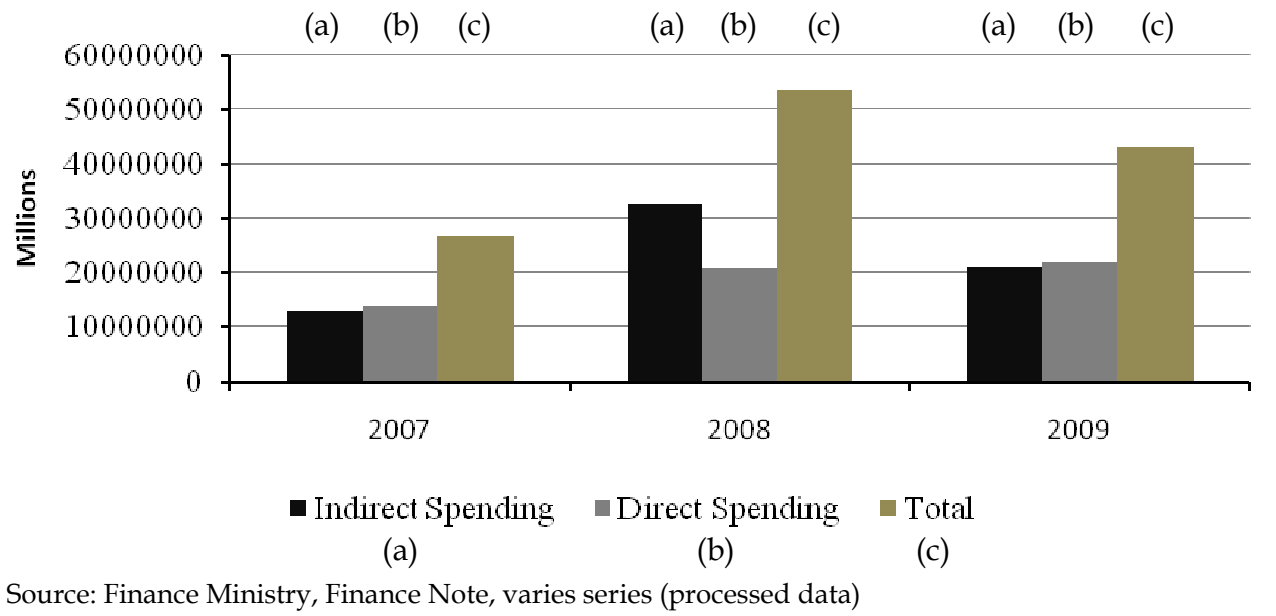

Figure 11. Trends in Regional Government Expenditure (Province, District/City) in Indonesia: 2007-2009 (in million rupiah) 
velopment activities. According to Barro and Sala-i-Martin (2000), this type of expenditure classified as non-productive expenditure or routine expenditure. This expenditure does not contribute directly to economic development. better for the interests of regional development by looking at the larger proportion than any other type of expenditure.

If the allocation of regional expenditure divided by composition, then during the period

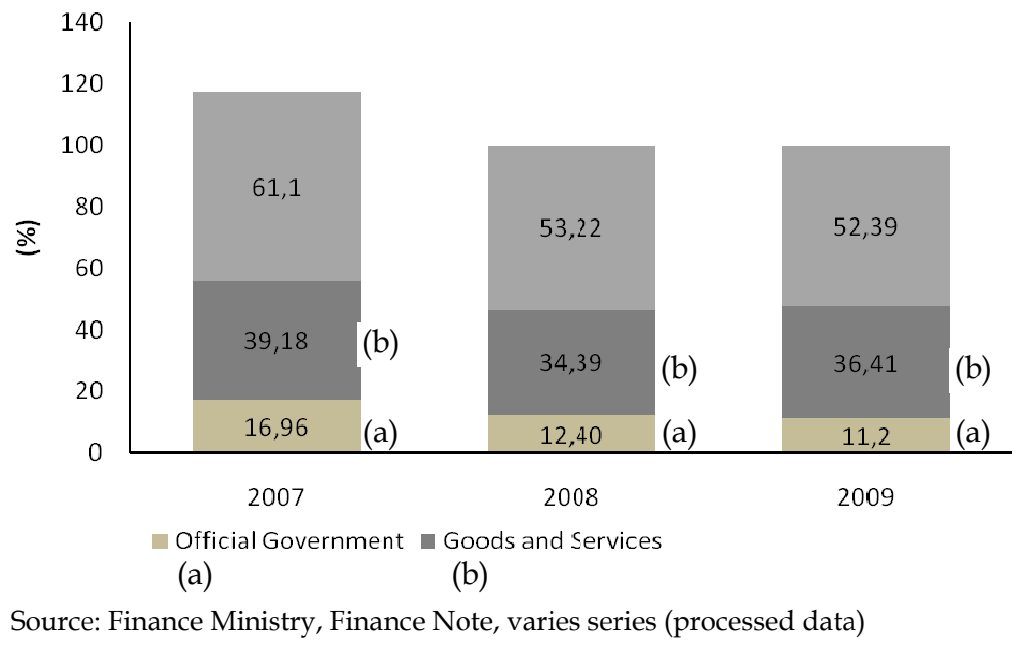

Figure 12. Trend Proportion of Direct Expenditure of Regional Government by Selected Expenditure in Indonesia, 2007-2009 (in percent)

The statement is proved by the distribution of indirect expenditures allocated to higher personnel expenditure. The number of personnel expenditure allocation was 74 percent of indirect expenditure in 2007 and decreased to 40 percent in 2008, the rest 60 percent was allocated in 7 kinds of other expenditures. In 2009, the allocation of personnel expenditure increases to 74 percent of total indirect expenditures. The rest 26 percent is allocated to the other 7 kinds of expenditure and is the largest financial aid for 9 percent and 6 percent of social assistance. In this case, the allocation of personnel expenditure increases by an average of 62.67 percent of indirect expenditures during the last three years.

Events that draw in direct expenditure, the proportion allocated to personnel expenditure tends to decrease each year with an average of 13 percent. Then for expenditure goods and services around 37 percent and the largest is for capital expenditure by an average of 56 percent during the period 2007-2009. Despite the tendency for the proportion of capital expenditure decreased until 2009, but it has shown towards
2007-2009, the share of personnel expenditure is the highest ranked an average of 37 percent of total regional government expenditure. Meanwhile, the share of goods expenditures reached 17 percent, 26 percent for capital expenditures and other expenditure of 18 percent. If government expenditure is divided by function or field, then in 2007, regional expenditures used to carry out public service function that ranks the top 35 percent of total regional expenditures. Furthermore, regional expenditures used to fund educational function reached 23 percent, 19 percent for the function of public housing, and health functions only 8 percent or below the allocation for the economic function of 10 percent.

It was mentioned that the degree of fiscal decentralization can be measured through three indicators: (1) expenditure indicators: the ratio of total government expenditure (provincial, district/city) to the state expenditure, (2) revenue indicators: the ratio of regional revenues (provincial, district/city) to state revenues, and (3) development expenditure: the ratio of regional government development expenditure 


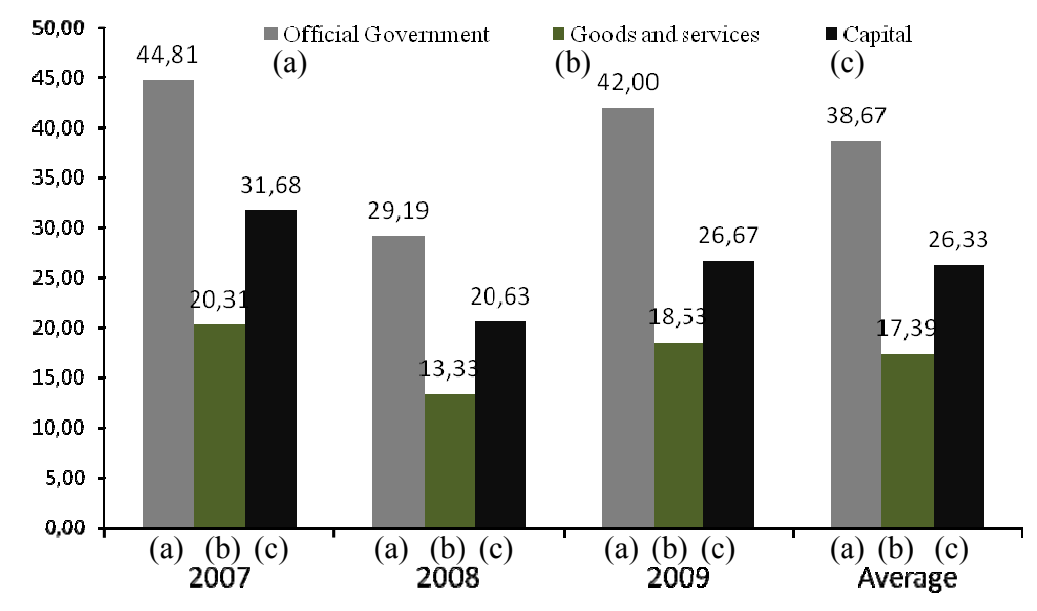

Source: Finance Ministry, Finance Note, varies series (processed data)

Figure 13. Regional Government Expenditure by selected expenditure in indonesia, 2007-2009 (in percent)

(provincial, district/city) to government development expenditure.

One of the indicators used here is an indicator of expenditure. There are three degrees of fiscal decentralization measures is shown in Figure 14: (1) the ratio of district/city expenditure to the national expenditure after deducting the subsidies, (2) the ratio of district/city expenditure to the total transfer, and (3) the ratio of district/city expenditure to total national expenditure. Based on the three measures, the degree of fiscal decentralization both provincial and district/city vary from year to year.

Degree of fiscal decentralization to districts based on three types of state expenditures appears to have increased for two years (20072008), although in the year 2009 (APBN) declined but the realization is expected to increase. The ratio of districts government spending of the national expenditure after the subsidy increased by an average of 44.78 percent per year. If the degree of fiscal decentralization using the ratio of government expenditures for district/city of the total transfers, it seems the ability of district/city looks big enough to fund the governmental affairs and development. This is indicated by the ratio reached an average of 115.99 percent. However,

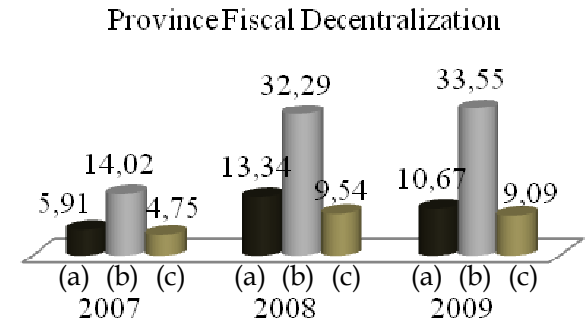

(a) NationalExpenditureminus Subsidies

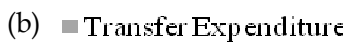

(c) Total National Expenditure
District/City Fiscal Decentralization

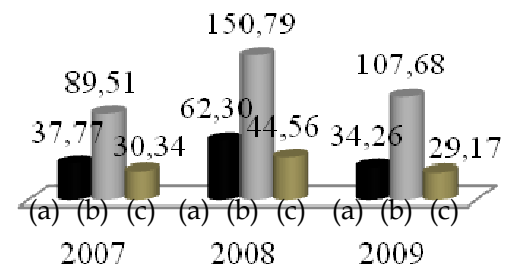

(a) National Expenditureminus Subsidies

(b) Transfer Expenditure

(c) Total National Expenditure

Source: Finance Ministry, Finance Note, varies editions (processed data)

Figure 14. Degree of Fiscal Decentralization in Province and District/City Indonesia, 2007-2009 by Expenditure Indicator 
if the total expenditure of district/city compared to the total national expenditures, the degree of fiscal decentralization is still considered low at only 34.6 percent.

In general one can say that government's ability District/City to finance the functions which are the responsibility has increased. The same thing for the province, the degree of fiscal decentralization is also showing signs encouraging enough, but the average ratio of the increase is not as much as at the district level. The ratio increased by an average 9.98 percent, 26.62 percent and 7.79 percent respectively (expenditures minus state subsidies), the total transfer fund, and the total national expenditure (Figure 14).

Fiscal decentralization has the objective to support the funding of affairs that has been submitted to the region, so that regions can improve the efficiency and effectiveness of public service. Through fiscal decentralization is expected to provide an opportunity for the region to improve the welfare of society, which in turn will promote economic development of regional development. However, the efforts of regional economic improvement and improvement of social welfare cannot be simply handed over to the fiscal decentralization policy. A good regional development can only be done if there is a balance of three pillars, namely the government, private sector, and society. All three each have the different functions and roles in carrying out the development. Government role is to create political and legal environment conducive to private sector and the community. Private sector role is to create jobs and income that should be supported by the government sector. Society plays a role in the creation of social interaction, economic, and political. Synergy between the three sectors in the era of regional autonomy should be implemented.

To analyze the success of fiscal decentralization may be associated with the success of regional economic development. There are several indicators that can be used, among others; regional economic growth, low inflation and stable, employment opportunities, increased investment and exports, and poverty reduction. Economic growth is one indicator to analyze the impact of fiscal decentralization on regional economic development. In 2006, the average economic growth of the region was 4.75 percent. In this year, there were 7 provinces were under the average and the 26 provinces were above average. In 2007, the average regional economic growth increased to 5.6 percent. There were 10 provinces that were below average and the 23 provinces were above average. By comparing with the performance of the national economic growth, there were 18 provinces that have economic growth rates above the national economic growth, 6.28 percent in 2007. South Sulawesi Province has the largest economic growth rates reached 11.2 percent. In 2008, the national economic growth has dropped to 6.06 percent. In this year, there were 11 provinces that were above the national economic growth. Papua Province is the highest reached 38.2 percent. The fluctuations of regional economic growth is determined by many factors, among others; economic and political conditions in the region, the potential of human resources, natural resources, and the effectiveness of regional financial management.

The success of fiscal decentralization also highly depends on the effectiveness of budget (APBD) expenditure policy. Expenditure of APBD has a very important role in the implementation of regional governance. Effectiveness of budget expenditures will directly influence the effectiveness of public services, which in turn will determine the success of regional development. Effectiveness of budget expenditure is influenced by internal factors and external regional government. Internal factor includes budget formulation process, the role of community participation, political support from the Parliament, while external factor such as synergy between regional programs and central government programs. These factors are still challenge for regional governments to realize. Budget formulation process is a challenge because the budget formulation process is not a simple process. This process is related to the planning mechanisms involving various parties with widely divergent interests. The challenge is how to create a clear relationship between inputs (budget in APBD) and outputs and out- 
comes of programs and activities. Budgets are just an end of the planning.

Community participation and political support is also crucial to the effectiveness of budget expenditures because these two elements determine the outcome to be achieved and at the same time assess whether regional governments have been successful. Another challenge is the external factor is how to create synergy between the programs and activities at the national level and regional policies. Expenditure budget becomes ineffective if not in line with national development programs, or vice versa. This is not a simple way to create synergy between programs and activities at various levels of government.

\section{CONCLUSION}

First, the trend of State government expenditure during the era of regional autonomy and decentralization shows the central government expenditure tends to decreased and the transfer expenditure tends to increased. The transfer has increased significantly every year in absolutely, but annual growth rate fluctuated considerably. This means that during the period of decentralization, the allocation portion of the transfers into the region was unstable. The fund balance is the largest component of transfers to the region which showed a significant increase every year and general allocation fund (DAU) is the largest components of fund balance.

Second, regional government expenditure for both provinces and District/City is more dominated by indirect expenditure than direct expenditure.

Third, degree of fiscal decentralization for districts/city shows increased for two years (2007-2008). The same thing for the province, the degree of fiscal decentralization is also showing signs encouraging enough. These mean that regional government's ability to finance their functions have encouraged. However, by looking at the development of direct and indirect expenditures, fund allocation for indirect expenditure is still bigger than direct expenditure.

Fourth, the success of fiscal decentralization highly depends on the effectiveness of budget (APBD) expenditure policy. Expenditure of APBD has a very important role in the implementation of regional governance. Effectiveness of budget expenditures will directly influence the effectiveness of public services, which in turn will determine the success of regional development.

Fifth, it is recommended to regional government (district/city and province) to improve public finance management and also to allocate bigger their budget for public interest than for government administration.

\section{REFERENCES}

Abimayu, Anggito, and Andie Megantara. 2009. New Era of Fiscal policy. Though, Concept, and Implementation. Jakarta: Kompas

Barro, R.J., and Sala-i-Martin. 1992. Public Finance in Models of Economic Growth. Review of Economic Studies 59 (201):645662.

Boex, Jameson and Martinez-Vazquez, Jorge. 2001. The Design of Equalization Grants: Theory and Applications (Part 1). Fiscal Decentralization: A Review of Concepts and Application for Indonesia. Fiscal Policy Summer Training Course. Andrew Young School of Public Studies. Georgia State University. Atlanta.

Fisher, 2007 Fisher, Ronald. C. 2007. State and Local Public Finance. South - Western: Thomson

Ichimura, Shinichi and Bahl, Roy. 2009. Decentralization Policies in Asian Development. Singapore: World Scientific Publishing Co.Pte.Ltd.

Khuzaini, M. 2006. Public Economics Fiscal Decentralization and Regional Development. Surabaya: BPFE Unibraw.

Martinez-Vazquez, Jorge and McNab, RM. 2001. Fiscal Decentralization And Economic Growth. ISP. Working Paper \#01-1 January 2001. Andrew Young School of 
Public Studies. Georgia State University. Atlanta.

Martinez-Vazquez and Sri Mulyani Indrawati, 2004. Reforming Intergovernmental Fiscal Relations and the Rebuilding of Indonesia. The Big Bang Program and its Economic Consequences. EE Cheltenham, UK. Northampton, MA, USA

Martinez-Vazquez, Jorge and Searle, Bob. 2007a. Fiscal Equalization Challenges in the Design of Intergovernmental Transfers. United States of America: Springer

Martinez-Vazquez, Jorge and Searle, Bob. 2007b. Challenges in the Design of Fiscal Equalization and Intergovernmental Transfer. In Fiscal Equalization Challenges in the design of Intergovernmental Transfer. United States of America. Springer

Martinez-Vazquez, Jorge and Sri Mulyani. 2004. Series Edition: Wallace E. Oates. Cheltenham, UK* Northampton, MA. USA. Edward Elgar Publishing Limited.

Financial Note of Republic of Indonesia, State Budget, 2001-2009.

Phillips, Kerk.L and Woller, Garry. 1997. Does Fiscal Decentralization lead to Economic Growth? Working Paper 97(7): September 1-13.

Rodriguez-Pose, Andres and Kroijer, Anne. 2009. Fiscal Decentralization and Eco- nomic growth in Central and Eastern Europe. Growth and Change 40(3):387-417.

Rosen, Harvey S and Gayer, Ted. 2008. Public Finance. Eight edition New York: McGraw Hill/Irwin Companies.

Simanjuntak, R and Mahi, B.Raksasa. 2004. Local Tax Revenue Mobilization in Indonesia's decentralizing era. In Reforming Intergovernmental Fiscal Relations and the Rebuilding of Indonesia. The Big Bang Program and Its Economic Consequences. Studies in Fiscal Federalism and State-Local Finance. Alm, James.

Searle, Bob and Martinez-Vazquez, Jorge. 2007. The Nature and Function of Tied Grants. In Fiscal Equalization Challenges in the Design of Intergovernmental Transfer Martinez-Vazquez and Searle. United States of America: Springer.

Suzan, Steiner. 2005. Decentralization and Poverty Reduction: A Conceptual Framework for the Economic Impact. http:// ideas.repec.org/wpa/wuwppe/0508006.h tml. Retrieved 2 April 2009.

Zhang, Tao and Heng-Fu Zou (1998). Fiscal Decentralization, Public Spending \& Economic Growth. Journal of Public Economics 67(2):221-40.

World Bank. 2007a Analysis of Public Expenditure in Gorontalo Province. 